\title{
Does male Chondracanthus lophii (Crustacea: Copepoda) feed?
}

\author{
Pia Østergaard \\ Department of Zoology, The Natural History Museum, Cromwell Road, London, SW7 5BD, UK and Department of Biological \\ Sciences, Imperial College London, Silwood Park Campus, Ascot, SL5 7PY, UK. E-mail: piao@nhm.ac.uk
}

\begin{abstract}
Male Chondracanthus lophii was studied using light and electron microscopy. Observations on external morphology and internal anatomy are presented. Males possess a full set of functional mouth parts, the digestive system is active and the dominant cell type in the midgut is identified as the vacuolar type B-cell, but the gut is a blind ending sac with no anus. The gut contents were a homogenous, amorphous mass. The combination of active feeding and digestion with a blind ending gut supports the inference that males feed on special secretions produced by glands in the nuptial organs of the female. It is speculated that dependence on such secretion reduces or eliminates the production of faecal matter. Observations on the reproductive system confirmed the typical chondracanthid pattern.
\end{abstract}

\section{INTRODUCTION}

Chondracanthus Delaroche, the type genus of the family Chondracanthidae Milne-Edwards, currently has 38 valid species (Ho, 1991; Østergaard, 2003) including Chondracanthus lophii Johnston. This species has been described several times under a variety of different names (see Kabata, 1979 for synonymy) but its biology is poorly known. Heegaard (1947) described the first nauplius stage, but did not succeed in rearing any further stages. Kabata (1979) redescribed the external morphology of both sexes including details of young adult females. The life-cycle of the closely related genera Acanthochondria Oakley and Pseudacanthocanthopsis Yamaguti \& Yamasu, comprises 3 nauplii, 5 copepodids and the adult (Izawa, 1986).

The males of all genera of Chondracanthidae are many times smaller than the females, and they are commonly referred to as dwarf males (e.g. Ho, 1970; Kabata, 1979; Rousset \& Raibaut, 1983). The males are not ephemeral (Kabata, 1979), but they are often overlooked, probably because of their small size. Chondracanthid males have no anus (e.g. Claus, 1861; El Saby, 1933; Rousset \& Raibaut, 1983) and it has been suggested that they lack a functional digestive system (Bourguet et al., 1993).

This paper addresses the question does the male of C. lophii feed, by presenting supplementary data on the external morphology of male C. lophii as revealed by scanning electron microscopy (SEM), and by providing data on the internal anatomy of the male, using both light (LM) and transmission electron microscopy (TEM).

\section{MATERIALS AND METHODS}

\section{Material}

Material of Chondracanthus lophii was obtained from gill pouches of Lophius piscatorius (Linnaeus, 1758) collected from trawls taken on RV 'Scotia', during cruise 0999S (01 to 04 June, 1999$)$ to Dutch Bank $\left(59^{\circ} 22^{\prime} \mathrm{N} 01^{\circ} 10^{\prime} \mathrm{W}\right)$ and $0800 \mathrm{~S}$ (26 to $29 \mathrm{May}, 2000)$ to Fair Isle $\left(59^{\circ} 12^{\prime} \mathrm{N}\right.$ $\left.01^{\circ} 26^{\prime} \mathrm{E}\right)$. Females with males attached were removed from the host by hand. The material was deposited in The Natural History Museum, London (BMNH 2002.191203).

\section{Light microscopy (LM)}

Two ovigerous females, each with one male, were cleared in lactic acid (98\%) and dissected parts were mounted in lactophenol $(20 \% \mathrm{w} / \mathrm{v}$ phenol). The dissected parts were examined on an Olympus BH2 D.I.C. microscope. Eight ovigerous females with males were treated using the same protocol as for TEM (see below) and cut in semithin sections $(1.0-1.5 \mu \mathrm{m})$, which were then stained with toluidine blue and examined in an Olympus Photomicroscope. Terminology of copepod anatomy follows Huys \& Boxshall (1991).

\section{Transmission electron microscopy (TEM)}

Fresh material was fixed in $4.5 \%$ glutaraldehydeformaldehyde mixture (with $0.2 \mathrm{M}$ cacodylate buffer, $\mathrm{pH}$ 7.4) added sodium chloride $(2.5 \%$ ) for seawater effect (modified from Karnovsky, 1965). Secondary fixation was performed in the laboratory using trialdehyde (with $0.2 \mathrm{M}$ cacodylate buffer, $\mathrm{pH}$ 7.4) and added sodium chloride $(2.5 \%)$ overnight (modified from Lake, 1973). Finally, the material was postfixed in $1 \% \mathrm{OsO}_{4}$ (buffered with $0.2 \mathrm{M}$ cacodylate, $\mathrm{pH}$ 7.4). After fixation, the specimens were left in $16 \%$ glycerol overnight on a rotating table (after Felgenhauer, 1987) to remove mucus, sand grains and other particles. The specimens were dehydrated through graded alcohol series and embedded in TAAB resin. Ultra-thin sections $(70-90 \mathrm{~nm})$ for TEM were stained with uranyl acetate and lead citrate and were examined in a Hitachi H7100 transmission electron microscope.

\section{Scanning electron microscopy (SEM)}

Five ovigerous females with males were fixed as for TEM and dehydrated through graded acetone series, then 

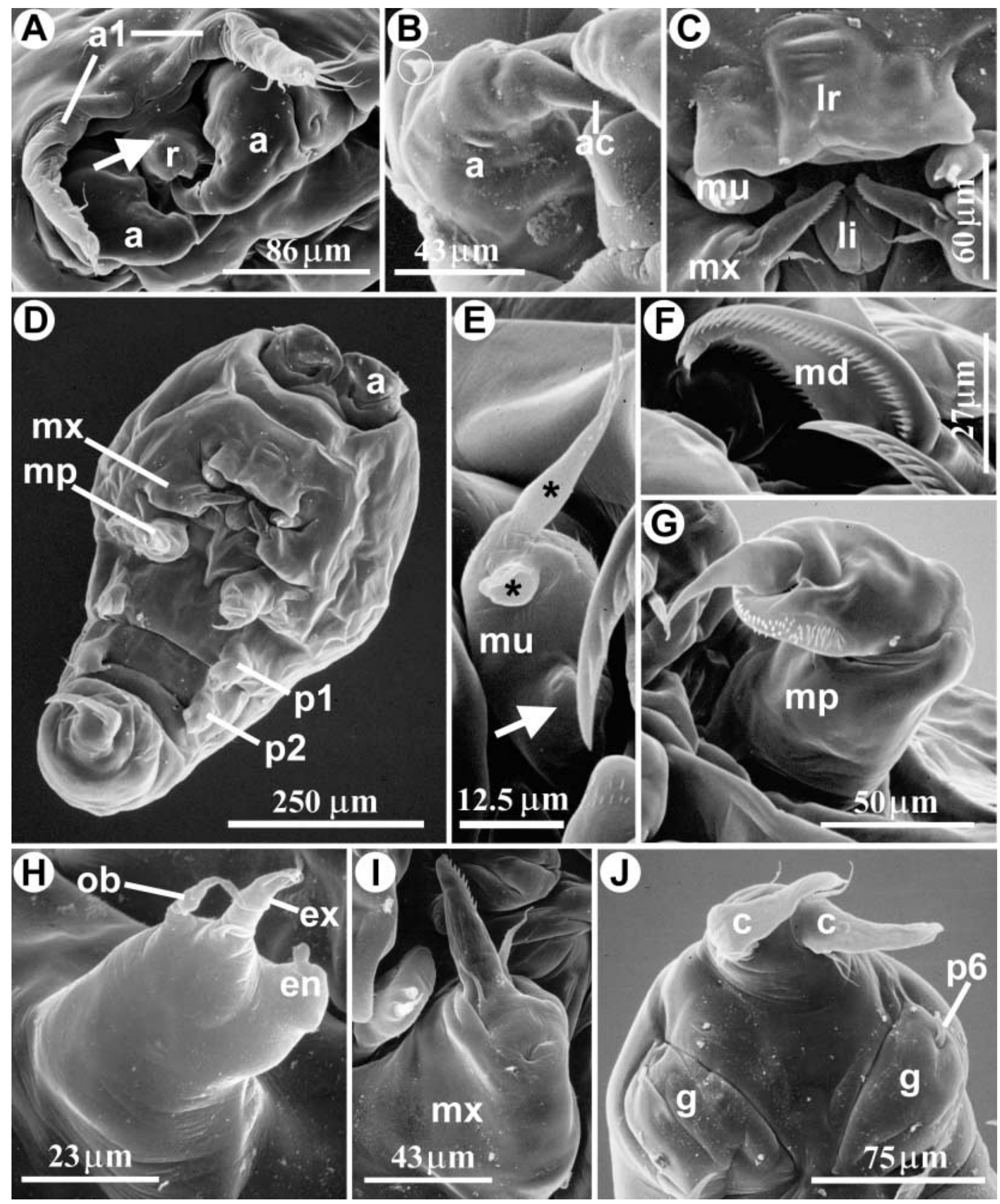

Figure 1. Scanning electron microscopy of male Chondracanthus lophii. (A) Anterior part of cephalosome with antennules (al), antennae (a) and rostrum (r). Median pore on rostrum arrowed; (B) antenna (a) with claw (ac) and atrophied tip (circled); (C) mouth area with labrum (lr), labium (li), maxillules $(\mathrm{mu})$ and maxillae $(\mathrm{mx})$; (D) ventral aspect of male showing antennae (a), maxillae ( $\mathrm{mx}$ ), maxilliped (mp), leg $1(\mathrm{pl})$ and leg $2(\mathrm{p} 2)$; (E) maxillule ( $\mathrm{mu}$ ) with setae (*) and prominence (arrow); (F) mandible (md); (G) maxilliped (mp); (H) leg 1 with outer basal seta (ob), endopod (en) and exopod (ex); (I) maxilla (mx); (J) ventral view of genito-abdomen showing genital opercula (g) with leg $6(\mathrm{p} 6)$, and caudal rami (c). 
critical point dried, mounted and sputter-coated with gold palladium. They were examined in a Hitachi S2500 scanning electron microscope.

\section{RESULTS}

Usually there is only one male per female. The female (length: $11-12 \mathrm{~mm}$ ) is about 20 times larger than the male, which is typically found attached to the female genital region, gripping onto the nuptial organs with their antennae (Figure 2A). In that location the genitoabdomen of the male is in close proximity to the paired genital openings of the female. The nuptial organs house active glandular tissue and produce secretory material which, it is postulated, is utilized by the male as a nutrient source.

\section{Morphology}

Most aspects of Kabata's (1979) redescription of male Chondracanthus lophii are confirmed but some supplementary observations are added.

Cephalosome subcircular in dorsal aspect. Trunk narrower than cephalosome, with external segmentation moderately well defined; incorporating genito-abdomen (Figure 1D). Body usually flexed, with ventral surface concave. Total length $0.50-0.75 \mathrm{~mm}$. Genital apertures paired, located ventrally on genito-abdomen (Figure $1 \mathrm{~J}$ ). Caudal rami tapering to finely pointed tip; bearing two ventral setae and one dorsal near base, as well as a minute cylindrical papilla on medial side in proximal part (Figure 1J).

Antennule with indistinct segmentation, a somewhat inflated, fleshy base and cylindrical terminal part with rounded tip: armed with two proximal and eight terminal setae (Figure 1A). Unpaired process located in midline just posterior to bases of antennules, provisionally identified as rostrum, with median pore apically (arrowed in Figure 1A). Antenna modified, 3-segmented, with broad coxobasis bearing one basal seta, and endopod of two segments (Figure 1B). Proximal segment massive, produced into powerful, curved claw. Atrophied tip of antenna, short, subcylindrical, with two digitiform protuberances. Labrum a rectangular, transverse flap without ornamentation (Figure 1G). Labium broad, with slight medial and paired lateral indentations in free posterior margin (Figure 1G). Mandible with squat segment drawn into falcate terminal blade serrate along both margins; $~ 36$ denticles on outer margin and 14 on inner margin (Figure $1 F)$. Paragnath not observed. Maxillule simple lobe with two relatively long apical setae and rounded prominence on medial margin (Figure 1E). Maxilla 2-segmented; syncoxa squat powerful, unarmed segment articulating with terminal, claw-like process, armed with one row of relatively large denticles (10-12) on outer margin; accessory spinule (auxiliary process) near base of claw on outer surface long and slender with subterminal ornamentation; short slender seta present near base (Figure 1I). Maxilliped 3-segmented, comprising syncoxa, basis and short distal subchela formed from endopod and terminal claw (Figure 1G). Syncoxa unarmed, basis ornamented with denticles in two patches, claw slender with inflated base and with hooklet (secondary tooth) on concave

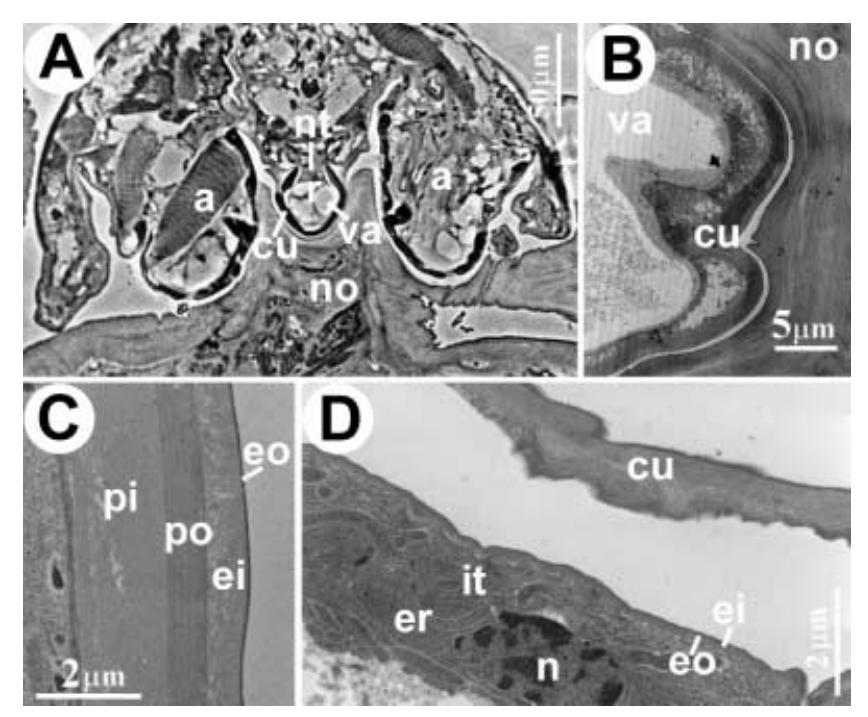

Figure 2. Photomicrographs of integument and rostrum in male Chondracanthus lophii. (A) Transverse semithin section of anterior region of male showing how male grasps female nuptial organ (no) with its robust, muscular antennae (a). Rostrum (r) has thick cuticle (cu), large vacuoles (va) and ventral nervous tissue (nt) and is lodged in the nuptial organ of the female; (B) TEM of rostrum. Abbreviations as in Figure 2A; (C) TEM of body cuticle, showing epicuticle consisting of outer (eo) and inner (ei) layers, and procuticle consisting of outer (po) and inner (pi) layers; (D) TEM of integument of adult male (it) and old ecdysed copepodid V cuticle (cu). The integument is composed of new cuticle (eo and ei) and an active epidermis with nucleus (n) and dense endoplasmic reticulum (er).

margin. Leg 1 bilobate, lateral lobe (corresponding to exopod) tapering, with two setae; medial lobe (corresponding to endopod) shorter, surmounted by papilla (Figure $1 \mathrm{H}$ ). Papilliform outgrowth present on medial margin near base; long lateral seta present (corresponding to outer basal seta). Leg 2 similar to leg 1 , never with papilliform outgrowth on medial margin. Legs 3 to 5 absent. Leg 6 represented by paired genital opercula armed with one seta (Figure 1J).

\section{Anatomy}

\section{Integument}

The integument is typical for free-living and ectoparasitic copepods with epicuticle and procuticle (cf. Bresciani, 1986). The multilayered epicuticle is less than $2 \mu \mathrm{m}$ thick (Figure 2G). The outer layer of the epicuticle is a thin $(\sim 0.05 \mu \mathrm{m})$, electron-dense zone with a dense array of tiny rounded cuticular knobs. The inner layer of epicuticle is the best developed $(\sim 0.7-1.5 \mu \mathrm{m}$ in thickness $)$ and is a more granular, electron-lucent, amorphous zone with a loosely arranged, homogenous network of fibrils and fine filaments. Procuticle is present in some regions of the body and is subdivided into two laminar zones, varying in thickness depending on position on the body. The outer layer is more electron-dense and is $\sim 0.75-2.0 \mu \mathrm{m}$ thick, the inner layer is more electron-lucent and is $\sim 2.0-$ $3.0 \mu \mathrm{m}$ thick (Figure 2G). The other component of the integument is the epidermis, but the boundaries between cells are often obscure (Figure 2D). The TEM of one male 


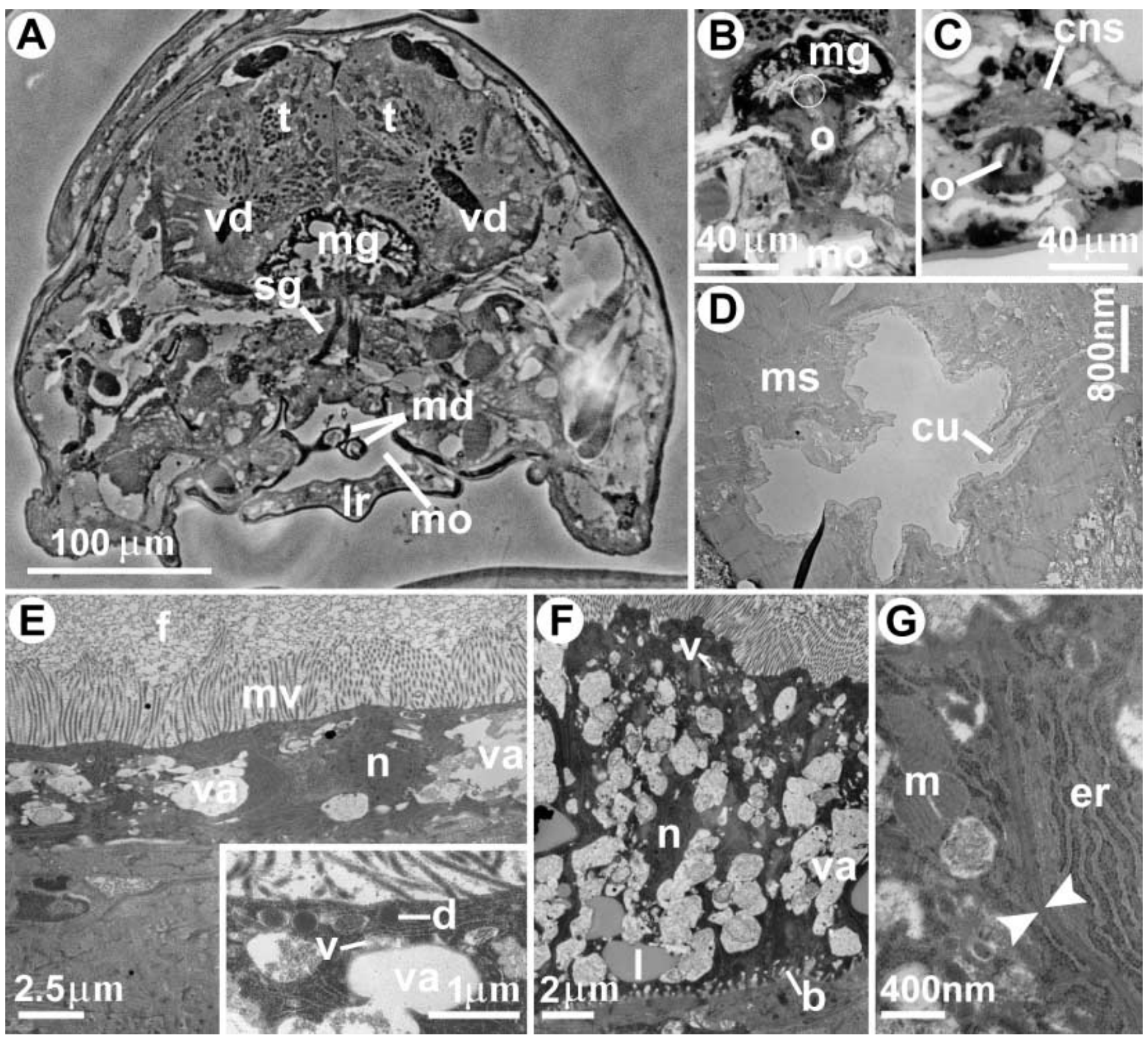

Figure 3. Photomicrographs of digestive system in male Chondracanthus lophii. (A) Transverse semithin section through mouth area showing central midgut $(\mathrm{mg})$, lying just dorsal to the suboesophageal ganglion $(\mathrm{sg})$. Tip of the mandibles (md) and the labrum (lr) are visible in mouth area $(\mathrm{mo})$. Note also the two testis lobes $(\mathrm{t})$ dorsal to the gut, which continue ventrally into the two vasa deferentia (vd); (B) transverse semithin section through oesophageal area showing the oesophagus (o) connecting mouth (mo) to gut $(\mathrm{mg})$, with a sphincter (circled) where the oesophagus opens into the midgut; $(\mathrm{C})$ transverse semithin section showing the oesophagus (o) and the cerebrum (cns); (D) TEM of the oesophagus showing the cuticle (cu) lining of lumen wall. Numerous constrictor and dilatator muscles (ms) are associated with the oesophagus; (E) TEM of midgut showing epithelium with apical microvilli (mv) and with ingested material (f) in the midgut lumen. Note also the nucleus (n) and numerous large vacuoles (va). Insert: showing detail of apical part of epithelial cell with dense bodies (d), and with vesicles (v) emptying their contents into vacuoles (va); (F) TEM showing detail of epithelial cell of type B with a central nucleus (n). Basally a large number of vacuoles (va) are present, together with lipid droplets (1). Basal lamina is invaginated (b); (G) TEM showing detail of the junction (arrows) between two epithelial cells. Note the abundant lamellar rough endoplasmic reticulum (er) and mitochondria $(\mathrm{m})$.

in the process of moulting from the final copepodid stage while attached to the female showed that epidermis in process of generating new cuticle has a high content of endoplasmic reticulum (Figure 2D).

\section{Rostrum}

The rostrum has a thick electron-dense cuticle covered by a thin and less electron-dense layer (Figure 2B). The core of the rostrum contains large vacuoles (lighter stained matter) and nerve tissue enters the rostrum basally (Figure 2A).

\section{Digestive system}

The mouth connects to the midgut via a short, cuticlelined oesophagus. The oesophagus ( $\sim 3 \mu \mathrm{m}$ in diameter $)$ is highly muscular, with constrictor and dilator muscles (Figure 3D). The oesophagus opens via a sphincter into the ventral side of the midgut (Figure 3B).

The midgut is simple, comprising an undivided main lumen located centrally (Figure 3A). It extends from the oesophageal area both anteriorly and posteriorly. The wall of the midgut is formed by epithelial cells with an apical brush border of long microvilli $(2.5 \mu \mathrm{m})$. The most 


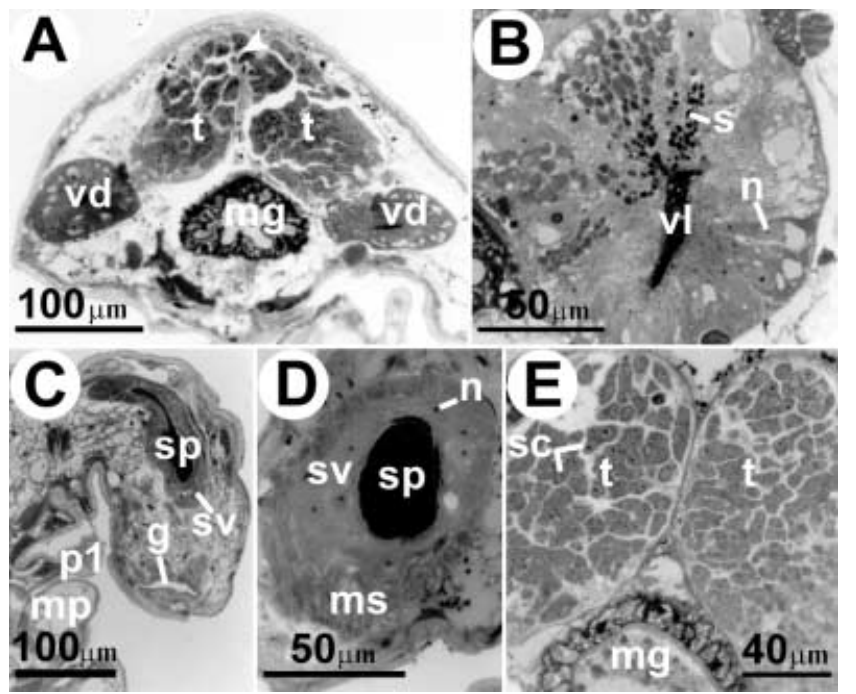

Figure 4. Photomicrographs of reproductive system in male Chondracanthus lophii. (A) Transverse semithin section anterior to the mouth area. The two testis lobes (t) lie dorsal to the gut $(\mathrm{mg})$. Note the testis bridge (arrow) dorsally and the two latero-ventral vasa deferentia (vd); (B) transverse semithin section showing the beginning of the vas deferens. Spermatids (s) are discharged from the testis lobe into the vas deferens lumen $(\mathrm{vl})$. Note the tall, columnar cells of the vas deferens wall with their nuclei $(\mathrm{n})$; (C) oblique longitudinal semithin section showing the posterior part of the male. Note the genital opening $(\mathrm{g})$, the seminal vesicle (sv), with a darkly stained spermatophore (sp) in its lumen. Antero-ventrally maxilliped (mp) and leg 1 (pl) are visible; (D) oblique transverse semithin section showing detail of the seminal vesicle (sv) with its cuboidal epithelial cells and their central nucleus (n). A darkly stained spermatophore (sp) fills up the lumen. Note the muscles $(\mathrm{ms})$ attaching to the seminal vesicle; (E) transverse semithin section posterior to the testis bridge showing the testis lobe $(\mathrm{t})$ full of spermatocytes (sc) located dorsal to midgut $(\mathrm{mg})$.

prevalent cell type observed is large $(5-15 \mu \mathrm{m}$ tall and wide), vacuolated and cuboidal (Figure $3 \mathrm{E}, \mathrm{F}$ ) with several pinocytotic vesicles apically. These cells contain a large number of vacuoles, the contents of which are heterogeneous. The vacuoles are larger towards the base of the cell. In the cytoplasm are numerous dense bodies $(0.2-0.4 \mu \mathrm{m}$ in diameter) particularly towards the lumen side of the cell (Figure 3E, insert). Lipid droplets are also present in the epithelial cells. Other cell characteristics include a centrally placed nucleus, lamellar rough endoplasmic reticulum and an invaginated basal lamina (Figure 3F,G). Few Golgi bodies and mitochondria were observed in the cells and this type of gut cell is comparable with the B-cell described by Arnoud et al. (1978) and Gresty (1992).

A second less abundant cell type was observed. This has denser cytoplasm and is more slender. These cells have more mitochondria, rough endoplasmic reticulum, and Golgi, and also have an invaginated basal lamina. They are probably either F- or D-cells as described by Arnoud et al. (1978).

Ingested material was present in the lumen (Figure 3E), but it was not possible to identify the nature of the food, which formed an amorphous mass. The midgut is a blind sac ending at the level where the spermatophore sacs start. No hindgut or anus is present (Figure $1 \mathrm{D}, \mathrm{J}$ ).

\section{Central nervous system}

A large dorsal cerebrum (Figure $3 \mathrm{C}$ ) is connected via circumoesophageal commissures, which pass laterally around the oesophagus to the suboesophageal ganglion (Figure 3A). The condensed ventral nerve cord tapers posteriorly from the suboesophageal ganglion.

\section{Reproductive system}

Most of the space in the male body is taken up by the reproductive system, which is symmetrical. The testis is bilobed, comprising a small germinal part with left and right lobes connected by a transverse bridge passing dorsally over the midgut (Figure 4A). In this transverse part spermatogenesis takes place (Figure 4E). Each testis lobe continues into a vas deferens where the young spermatids are released into the lumen (Figures 3A \& 4B). The cells in the vas deferens are tall, columnar with darkstaining cytoplasm and with nuclei predominantly located in the apical part (Figure 4B). The lumen of the vas deferens contains dark homogeneous secretion. Each vas deferens dilates distally into an elongate seminal vesicle where the spermatids are packed into spermatophores (Figure 4C). The cells of the seminal vesicle wall are squamose and the vesicle is surrounded by muscles (Figure 4D). A darkly stained spermatophore is present in the duct (Figure 4C,D). The vasa deferentia open near the tip of the urosome via paired genital apertures (Figures 1J \& $4 \mathrm{C})$.

\section{DISCUSSION}

Bourguet et al. (1993) stated that male Chondracanthus angustatus lacked a functional digestive system. In contrast, the digestive system in male $C$. lophii is not vestigial, but appears to be actively involved in the uptake of nutrients. There are well developed mouth parts, a functional oesophagus, and the midgut epithelial cells contain lots of vesicles and lipid droplets stored in the epithelium. Extensive pinocytosis in the apical part of the B-cells was observed, which indicates ingestion of material. The heterogenous vacuoles and numerous dense bodies also support the inference that absorption of digested material is taking place.

I was unable to distinguish the presence of all the distinct cell types in the gut epithelium, as found, for example, in the copepods Centropages typicus Krøyer, 1849 and Myticola intestinalis Steuer, 1902 (Arnoud et al., 1978; Gresty, 1992 respectively). The dominant cell type in Chondracanthus lophii is here identified as the vacuolar cell type (B-cell), defined by Arnoud et al. (1978), which facilitates cell secretion, excretion and absorption. The B-cell typically dominates the middle zone of the midgut (Arnoud et al., 1978). Arnoud et al. (1978) recognized five stages in the development of epithelial cells but the B-cells observed in this study were all apparently at the same developmental stage. The second cell type found in this study may be an F- or a D-cell, both of which are involved in the synthesis and secretion of enzymes (Boxshall, 1992).

Nott et al. (1985) described the cyclical development and sloughing of intestinal cells in the free-living Calanus 
helgolandicus (Claus, 1863), which has a typical digestive system including a hindgut and anal opening. Sloughing of cells contributes to the production of faecal pellets, which are then passed through the anus. Gresty (1992) in her study of the parasitic copepod M. intestinalis also found an active gut with an anus. She identified all the different cell types described by Arnoud et al. (1978) in the midgut and also observed sloughing of B-cells. The gut in Chondracanthus lophii is a blind ending sac with no anus, which is not unusual in highly transformed parasitic copepods (e.g. Claus, 1861; El Saby, 1933; Rousset \& Raibaut, 1983; Østergaard, 1998). The cell cycle for a copepod with no anus may well differ from that of a copepod with a functional anus, since the production of faecal pellets would be problematic, as there is no way to dispose of them. In C. lophii there is a preponderance of cells of the same type and at the same developmental stage, and I did not observe any of those cells in sloughing phase. The epithelium in C. lophii is highly absorptive and if the food ingested is easily digestible, then production of faecal matter will be minimized. Any such material produced during digestion would have to be stored since it cannot be eliminated. There was no evidence of stored waste material.

The digestive and reproductive systems in both C. angustatus (cf. Rousset et al., 1978) and Lernentoma asellina (cf. Rousset \& Raibaut, 1983) are similar to those described here. The reproductive system is well developed and symmetrical, producing paired spermatophores. The energy to this investment in reproduction must come either from stored resources, such as lipid, or from feeding. Neither Rousset et al. (1978) nor Rousset \& Raibaut (1983) could identify the nature of the ingested material. The gut contents of $C$. lophii were homogenous and amorphous. It is suggested that $C$. lophii males feed on a secretion produced by the female in glands associated with the paired nuptial organs. Dependence on such a secretion may reduce or eliminate the production of waste material. It may be the ideal nutrient source for a copepod with a blind ending digestive system.

The author is grateful to staff in the Electron Microscopy Unit at The Natural History Museum. Special thanks are due to J. Bresciani, Royal Veterinary and Agricultural University, Denmark and G.A. Boxshall, The Natural History Museum, UK for invaluable discussions on copepod morphology during the preparation of this paper.

\section{REFERENCES}

Arnoud, J., Brunet, M. \& Mazza, J., 1978. Studies on the midgut of Centropages typicus (Copepod, Calanoid). Cell and Tissue Research, 187, 333-353.

Bourguet, D., Lambert, A., Raibaut, A. \& Renaud, F., 1993. L'insolite nanisme de crustacés parasites. Recherche, 24, 454-456.

Boxshall, G.A., 1992. Copepoda. In Microscopic anatomy of invertebrates. Vol. 9. Crustacea (ed. F.W. Harrison and A.G. Humes), pp. 347-384. New York: Wiley-Liss, Inc.
Bresciani, J., 1986. The fine structure of the integument of freeliving and parasitic copepods. A review. Acta Zoologica (Stockholm), 67, 125-145.

Claus, C., 1861. Ueber den Bau und die Entwicklung von Achtheres percarum. Zeitschrift für Wissenschaftlige Zoologie, 11, 287308.

El Saby, M.K., 1933. The internal anatomy of several parasitic Copepoda. Proceedings of the Zoological Society of London, 4, 861869.

Felgenhauer, B.E., 1987. Techniques for preparing crustaceans for scanning electron microscopy. Fournal of Crustacean Biology, 7, $71-76$.

Gresty, K., 1992. Ultrastructure of the midgut of the copepod Mytilicola intestinalis Steuer, an endoparasite of the mussel Mytilus edulis L. Fournal of Crustacean Biology, 12, 169-177.

Heegaard, P., 1947. Contribution to the phylogeny of the Arthropods. Copepoda. Spolia Zoologica Musei Hauniensis, 8, 1236.

Ho, J.S., 1970. Revision of the genera of the Chondracanthidae, a copepod family parasitic on marine fishes. Beaufortia, 229, $105-218$.

Ho, J.S., 1991. Redescription of Chondracanthus zei Delaroche (Copepoda, Poecilostomatoida) parasitic on Zeus faber L. in the Sea of Japan, with a preliminary review of the genus. Report of the Sado Marine Biological Station, Niigata University, 21, $49-79$.

Huys, R. \& Boxshall, G.A., 1991. Copepod evolution. Vol. 159: pp. 468. London: The Ray Society.

Izawa, K., 1986. On the development of parasitic copeoda. IV. Ten species of Poecilostome Cyclopoids, belonging to Taeniacanthidae, Tegobomolochidae, Lichomolgidae, Philoblennidae, Myicolidae, and Chondracanthidae. Publications of Seto Marine Biological Laboratory, 31, 81-162.

Kabata, Z., 1979. Parasitic copepoda of British fishes. Vol. 152: pp. 468. London: The Ray Society.

Karnovsky, M.J., 1965. A formaldehyde-glutaraldehyde fixative of high osmolarity for use in electron microscopy. Fournal of Cell Biology, 27, 137A.

Lake, P.S., 1973. Trialdehyde fixation of crustacean tissue for electron microscopy. Crustaceana, 24, 244-246.

Nott, J.A., Corner, E.D.S., Mavin, L.J. \& O’Hara, S.C.M., 1985. Cyclical contributions of the digestive epithelium to faecal pellet formation by the copepod Calanus helgolandicus. Marine Biology, 89, 271-279.

Østergaard, P., 1998. An anatomical and developmental study of an endoparasitic copepod Parachordeumium amphiurae (Hérouard) living in the brittlestar Amphipholis squamata (delle Chiaje). Zoologischer Anzeiger, 236, 189-202.

Østergaard, P., 2003. Catalogue of genera and species of the family Chondracanthidae Milne Edwards, 1840 (Copepoda: Poecilostomatoida) with notes on morphology. Systematic Parasitology, 55, 135-150.

Rousset, V. \& Raibaut, A., 1983. Integration of new structural characters to the systematic of Chondracanthidae (Copepoda, Poecilostomatoida). Bulletin de la Société Zoologique de France, 108, 115-127.

Rousset, V.A., Manier, J.-F. \& Coste, F., 1978. Reproduction et sexualité des copépodes parasites de poissons. 1. Lappareil reproducteur de Chondracanthus angustatus Heller, 1865: anatomie, histologie et spermiogenèse. Zeitschrift für Parasitenkunde, 55, 73-89.

Submitted 5 December 2003. Accepted 31 March 2004 